\title{
STUDY OF LOWER EXTREMITY DYSFUNCTIONS IN ADOLESCENT FOOTBALLERS
}

\author{
Krutali Saiprasad Ghogale *, Riddhi Shroff.
}

D.Y. Patil Deemed to be University, School of Physiotherapy, Nerul, Navi Mumbai, Maharashtra, India.

\section{ABSTRACT}

Background: Football is the most popular sport worldwide. Although participation in football leads to significant physical benefits, high velocity trauma and direct contact between the players have made football a kind of sport, connecting both the consequences of chronic overuse and acute injuries. There is a growing interest witnessed in football amongst younger age groups participating at a competitive level. However, increased participation predisposes the immature skeleton to injuries. The prevention of injury is important to minimize problems in the adolescent age group. Thus the purpose of our study is to evaluate lower extremity domains affected in male adolescent football players.

Methodology: The study subjects included were from club, district and state level football associations in the age group of 12 to 18 years. Demographic data and Lower Extremity Functional Scale was recorded.

Results: The players showed affection of these activities: difficulty while running on uneven ground, in making sharp turns while running and hopping.

Conclusion: The study concluded that there was mild impairment affecting the lower extremity function in football players.

KEY WORDS: Function, Footballers, Adolescence, Activities, Impairment.

Address for correspondence: Dr. Krutali Saiprasad Ghogale, D.Y. Patil Deemed to be University, School of Physiotherapy, Nerul, Navi Mumbai, Maharashtra, India.

E-Mail: krutalighogale97@gmail.com

Access this Article online

Quick Response code

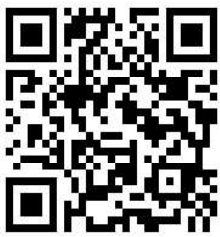

DOI: $10.16965 /$ ijpr.2020.136

Journal Information

International Journal of Physiotherapy and Research ISSN (E) 2321-1822 | ISSN (P) 2321-8975

https://www.ijmhr.org/ijpr.html DOI-Prefix: https://dx.doi.org/10.16965/ijpr

\section{Article Information}

Received: 03 May 2020

Peer Review: 05 May 2020

Revised: None
Accepted: 21 May 2020

Published (O): 11 Jul 2020

Published (P): 11 Aug 2020

\section{INTRODUCTION}

Football is one of the most popular sport worldwide, with about 200 million players, both professionals and amateurs [1]. Football is a popular sport in India with growing interest in younger age groups participating at a competitive level. India is one of the youngest nations in the World, with about $65 \%$ of the population under 35 years of age. The youth in the age group of $15-29$ years comprise $27.5 \%$ of the population. The government of India is promoting football as a sport of choice in adolescent age group since 2017 with various programmes namely Mission XI Million, Khelo India, etc. Mission XI Million is India's largest school contact programme that aims to change the perception towards football at the school level in India. The final objective of football becoming a sport of choice in India in the future [1]. High velocity trauma and direct contact between sportsmen in football leads to chronic overuse and acute injuries [2]. Increased participation in adolescent age group predisposes the immature skeleton to injury. Injuries can be caused 
by different factors such as collision with an athlete, moving object, overuse, overstretched ligaments, rapid acceleration or deceleration [3]. Previous studies done by Richard D Hawkins, Colin W Fuller in adolescent football players demonstrates that the most affected is hip, groin, thigh, knee, lower leg, ankle, foot and toes [4]. $86-100 \%$ of players are injured during each season $[5,6]$. Recurrent injury accounts for $22 \%$ of all injuries [7]. The result of the present study suggests that injuries that cause a high injury burden, and consequently in more missed matches and decreased match availability, are more likely to impact negatively on team performance [8]. There is growing popularity for football in the adolescent age group, due to intense participation in the absence of appropriate training and warm-up there is an increase in the number of children presenting with injury in the UK [9].

The early identification, prevention, and treatment of significant sporting injury in the younger players aims to minimize long-term functional impairment. The prevention of injury is crucial to minimizing problems with longer-term degenerative joint disease and persistent dysfunction in this young age group which hinders player's performance [10].

\section{MATERIALS AND METHODS}

This study was a cross sectional study where the subjects were male adolescent football players. After taking informed consent, self-made demographic questionnaire and Lower Extremity Functional Scale were administered to the male players in the age group of 12 to 18 years and the exclusion criteria was footballers who have been playing for less than one year, had any neurological involvement, any history of cardiovascular involvement. The material used was the Lower Extremity Functional Scale (LEFS). The LEFS is a questionnaire containing 20 questions about a person's ability to perform everyday tasks. The LEFS can be used as a measure of subject's initial function, ongoing progress and outcome, as well as to set functional goals [11].

The demographic questionnaire pertained questions regarding the frequency of play, level of play and previous history of a musculoskeletal injury.
Table 1: Characteristics of participants.

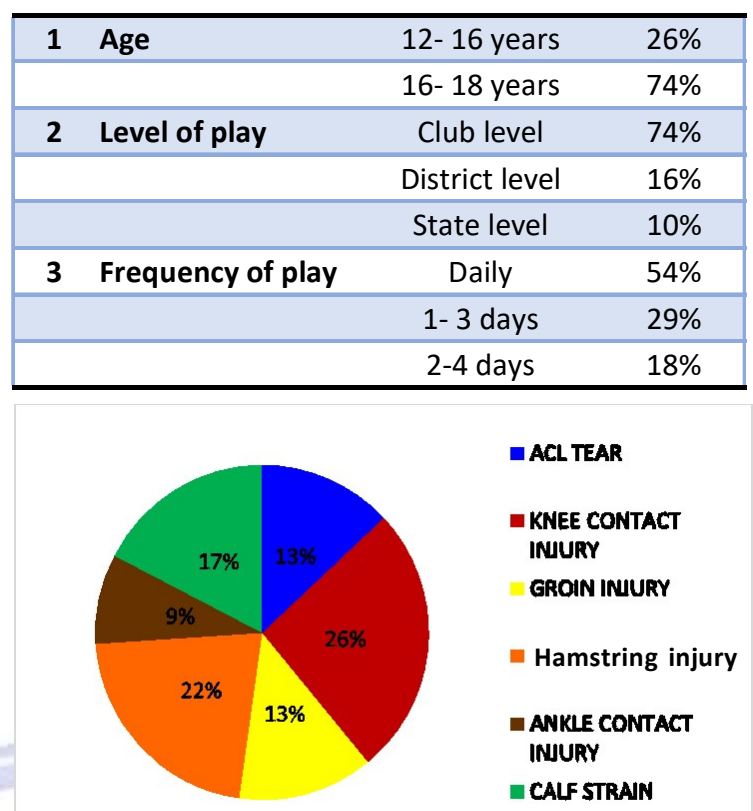

Fig. 1: The above pie chart shows the distribution of previous injuries encountered by the football players. 26\% Knee contact injuries, 22\% Hamstring strain, $13 \% \mathrm{ACL}$ tears, $13 \%$ Groin injuries, $17 \%$ Calf strain and $9 \%$ Ankle contact injuries.

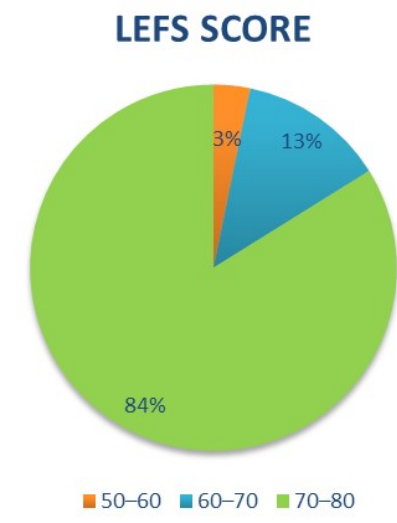

Fig. 2: The above pie chart shows the total LEFS Score amongst the football players. $78 \%$ lie in $70-80$ range and $12 \%$ lie in $60-70$ range whereas $3 \%$ lie in $50-60$ range of the LEFS score.

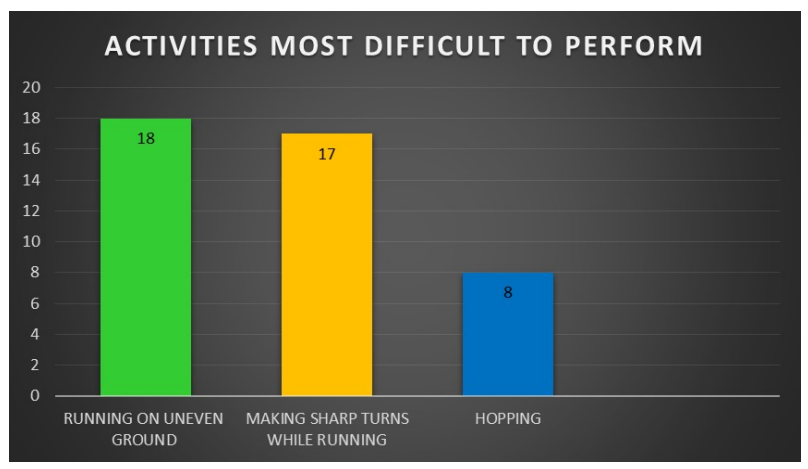

Fig. 3: The above graph shows the activities most commonly affected in the football players. $18 \%$ have difficulty while running on uneven ground, $17 \%$ have difficulty in making sharp turns while running whereas $8 \%$ while hopping. 


\section{DISCUSSION}

Our study describes key epidemiological data and highlights potential modes of injury in the lower extremity and its prevention. The present survey study investigated the incidence of musculoskeletal injuries among 100 male adolescent football players. Our study shows that the most common injuries that affected the adolescent football players during the game are, Lower Extremity Fractures (31\%), ACL Tears (23\%), Groin injury (23\%), Knee Joint Contact Injuries (15\%) and Ankle Joint Contact Injuries (8\%) as compared to previous studies done by Richard D Hawkins, Colin W Fuller in adolescent football players which showed ankle (17 - 26\%), and knee (17 - 23\%) as the most affected. In youth players the most affected by the injury was the lower extremity ( $61-89 \%)$, followed by the head/trunk/spine (9.7-24.8\%) and the upper extremity (4-24.8) [12]. Our study shows that maximally affected activities in male adolescent football players are, running on uneven ground (18\%), making sharp turns while running (17\%) and hopping (8\%) as compared to other studies.

A study done by Mirek et.al in 2019 supports that LEFS as an outcome measure used for children and adolescents with unilateral lower extremity chronic pain have clinical utility for tracking physical function changes following interdisciplinary treatment [15].

Previous studies have reported that during growth spurt, linear growth occurs in bones first, followed by soft tissues and during this growth spurt adolescent boys experience reduced flexibility which is seen more in the ones actively participating in sports like football. The reason for which maybe that the patellofemoral joint reaction force (PFJR) acts perpendicular to the articular surface and increases with increasing knee flexion [13]. Previous study also concludes that as compared to adults the long bones in children are able to absorb more energy before breaking and the presence of growth plates and apophysis for the attachment of musculotendinous structures lead to different spectrum of injuries compared with adults. Both epiphyses and apophysis have physes that grow and develop by endochondral ossification, apophysis have physes similar to epiphyses, but in contrast to epiphyses do not participate in longitudinal growth, are usually not perpendicular to the long axis of bone, are not articular, and are subjected to tension forces rather than to compression [14].

Another reason for lower extremity dysfunction could be soft tissue tightness which is common during adolescent growth spurt which results in inflexibilities altering the stress through the patellofemoral joint which includes tight quadriceps, patellar tendon and hamstring, thus increasing the PFJR. Inflexibility of gastrocnemius leads to increased subtalar position [10]. Other inflexibilities include tightness of piriformis muscle, iliotibial band. Repetitive injuries to this structures without proper recovery time leads to increase in the soft tissue tightness.

We are aware of the limited number of knee injury prevention programmes practiced in the USA which are designed to reduce injuries to the anterior cruciate ligament through neuromuscular training schedules [3]. To the best of researcher's knowledge few such schemes are available in India. The principal preventative focus in adolescents should be on the development of co-ordination, balance and body awareness. Those adolescent footballers with delayed skeletal development should be highlighted and specific attention must be given to training and conditioning so as to minimize the risk of injury. Emphasis should be placed on strengthening, endurance and proprioception, with full-time training [7].

\section{CONCLUSION}

Our study concludes that the lower extremity function in adolescent footballers shows mild impairment. The most common injuries that affected the adolescent football players are, Lower Extremity Fractures (31\%), ACL Tears (23\%), Groin injury (23\%), Knee Joint Contact Injuries (15\%) and Ankle Joint Contact Injuries (8\%). Maximally affected activities are, running on uneven ground (18\%), making sharp turns while running (17\%) and hopping (8\%).

Clinical Implications: By early identification of the most common activities affected in adolescent football players, it will help us to formulate rehabilitative strategies which will 
help in increase their performance and function.

\section{ACKNOWLEDGEMENTS}

I take this opportunity to express my sincere gratitude to those people without whose support and concern this project would not have been a success. I am also thankful to Dr. Unnati Pandit, Professor and Director, The School of Physiotherapy, D.Y. Patil University, Nerul for giving me the opportunity to initiate the project in this Institution and has given her valuable advice and help throughout. Needless to say, that all my study subjects also deserve a word of thanks for their co-operation. Also special thanks to my parents and brother without whose support my study would not have been possible.

\section{Conflicts of interest: None}

\section{REFERENCES}

[1]. Press Information Bureau, Government of India, Ministry of Youth Affairs and Sports.

[2]. Waldeìn $M$, Hagglund $M$, Ekstrand J. Injuries in Swedish elite football- -a prospective study on injury definitions, risk for injury and injury pat- tern during 2001. Scand J Med Sci Sports 2005:15(2):118-125. https://doi.org/10.1111/ j.1600-0838.2004.00393.x PMid:15773867

[3]. Fuller CW, Ekstrand J, Junge A, Andersen TE, Bahr R, Dvorak J, Hagglund M, McCrory P, Meeuwisse WH. Consensus statement on injury definitions and data collection procedures in studies of football(soccer) injuries. Clin J Sport Med 2006;16(2):97-106. https:/ /doi.org/10.1097/00042752-200603000-00003 PMid:16603877

[4]. Hawkins RD, Fuller CW. An examination of the frequency and severity of injuries and incidents at three levels of professional football. Br J Sports Med 1998:32(4):326-332. https://doi.org/10.1136/ bjsm.32.4.326 PMid:9865406 PMCid:PMC1756112

[5]. De Mozzi P, Longo UG, Galanti G, Maffulli N. Bicuspid aortic valve: a literature review and its impact on sport activity. Br Med Bull 2008:85:63-85. https:// doi.org/10.1093/bmb/ldn002 PMid:18296454

[6]. Lewin G. The incidence of injury in an English professional soccer club during one competitive season. Physiotherapy 1989; 75:601-5. https:// doi.org/10.1016/S0031-9406(10)62366-8
[7]. McGregor JC, Rae A. A review of injuries to professional footballers in a premier football team (199093). Scott Med J 1995; 40:16-18. https://doi.org/ 10.1177/003693309504000107 PMid:7604236

[8]. Hawkins R.D., Fuller C.W.: A prospective epidemiological study of injuries in four English professional football clubs, Brit. Sports Med. 1999;33:196-203. https://doi.org/10.1136/bjsm.33.3.196 PMid:10378073 PMCid:PMC1756169

[9]. Martin Hägglund et.al. Injuries affect team performance negatively in professional football: an 11year follow-up of the UEFA Champions League injury study. British Journal of Sports Medicine, 2013;(47):12:738-742. https://doi.org/10.1136/ bjsports-2013-092215 PMid:23645832

[10]. Flynn JM, Lou JE, Ganley TJ. Prevention of sports injuries in children. CurrOpinPediatr 2002;14:71922. https://doi.org/10.1097/00008480-20021200000015 PMid:12436044

[11]. Binkley JM, Stratford PW, Lott SA, Riddle DL. The Lower Extremity Functional Scale (LEFS): scale development, measurement properties, and clinical application. North American Orthopaedic Rehabilitation Research Network. Phys Ther. 1999 Apr;79(4):371-83. https://doi.org/10.1037/t35109000

[12]. Reilly DT, Martens M. Experimental analysis of the quadriceps muscle force and patello-femoral joint reaction force for various activities. Acta Orthopaedica Scandinavica 1972;43(2):126-137. https://doi.org/10.3109/17453677208991251 PMid:5079747

[13].Dr. Thomas Muller.2012 univallepublik ationenanzeigen; knieschmerz-beim-jugendlichen. $\mathrm{htm}$ accessed on -10/2/2014.

[14]. Kristin M Houghton. Review for the generalist: evaluation of anterior knee pain. Paediatric Rheumatology 2007; 5:8. https://doi.org/10.1186/1546-00965-8 PMid:17550634 PMCid:PMC1887528

[15]. Mirek et.al. Physical Therapy Outcome Measures for Assessment of Lower Extremity Chronic Pain-Related Function in Paediatrics. Pediatric Physical Therapy: April 2019;31(2):200-207. https:/ /doi.org/10.1097/PEP.0000000000000587 PMid:30865142

How to cite this article:

Krutali Saiprasad Ghogale, Riddhi Shroff. STUDY OF LOWER EXTREMITY DYSFUNCTIONS IN ADOLESCENT FOOTBALLERS. Int J Physiother Res 2020;8(4):3517-3520. DOI: 10.16965/ijpr.2020.136 